\section{Against Lysenko}

SAKHAROv's name first achieved wide currency among biologists rather than physicists. These were the years of the bitter struggle against Lysenko who had set Soviet science back decades. Paradoxical as it may seem, the 'healing' of Soviet biology began from the outside, from a direction not under the control of Lysenko. The rebirth of genetics, and later of many other biological disciplines, was assisted by physicists. At this stage, Sakharov - with conviction, and with specifically sakharovian thoroughness - began his struggle against Lysenko.

In 1959 he published a large article entitled "The Radioactive Carbon of Nuclear Explosions and Nonthreshold Biological Effects" in which he criticized the view of Edward Teller, who had declared that the adverse effects of hydrogen-bomb testing were "the equivalent of smoking one cigarette twice a month". Sakharov made a precise mathematical calculation of the disturbance of the hereditary molecules from neutron action and estimated the various side effects of irradiation. In a very concise way he showed the role of mutations in the appearance of hereditary diseases, and the possibility of increase in cancer and leukaemia, of decrease in the immunological response of organisms, and of damage done to mankind because of an increase in the mutability of bacteria and viruses.

Having investigated the effect of radiation on heredity, Sakharov was able, in addition, to clarify for himself the damage being done by lysenkoism. That done, he boldly joined in the battle against Lysenko and the lysenkoites, especially against Lysenko's protégé, N. Nuzhdin. By this time Tamm and Sakharov had become legendary figures in biological circles.

It seems to me that the struggle by Andrei Dmitrievich for the interests of science was a turning point for him. It brought to light something in him that singled him out from among many colleagues: a capacity for public activity, fearlessness and adherence to the highest moral principles. In the years when he was speaking out against lysenkoism, he had not yet proved to be a fighter for the ideals of humanism - something that was to bring him world recognition. This was perhaps his first test of strength. But it was a test that clearly showed the character of this amazing man. Valery N. Soyfer

Valery N. Soyfer is in the Department of Molecular Genetics and the Ohio State Biotechnology Center, Ohio State University, Columbus, Ohio 43210, USA. structure of marxist ideology had a great appeal for Russian intellectuals. Second, experience shows that families within the Soviet Union who themselves managed to avoid becoming Stalin's victims, would remain loyal to this ideology - the twentieth century has been not so much the century of the atom or the electronics industry, as that of the realization of the immense possibilities of mass propaganda. As Machiavelli knew, a ruler must "inspire terror in such a way that if he does not deserve affection, he does avoid hate". Third, since 1948 Sakharov had been working with enthusiasm behind the curtain of secrecy. He was involved in work of the utmost importance (according to his own views) for the preservation of world peace. It was only later, when he came to realize that the nation's cynical and politically unacceptable leaders had exploited him for their own ends, and when he learned more about the suffering of ordinary people, that his views began to change. It took a rather long time. But when his mind cleared he came to a new and deep understanding, and from then nothing could stop him immersing himself in political activity.

\section{Disarmament}

It is absolutely wrong to think (as many people do) that Sakharov's political activity was a kind of repentance for the 'sin' of participation in the bomb making. At that time, as well as later, most physicists believed that the world would not be safe if one power had a monopoly on nuclear weapons. Even in 1944, Niels Bohr was greatly troubled by this, as later were Albert Einstein and Bertrand Russell. I remember Landau (who himself had been jailed under Stalin, but who nevertheless took some part in the thermonuclear project) saying to me many times in the $1960 \mathrm{~s}$ : "Good for physicists - they saved the world from war".

Sakharov was of the same opinion. There was perhaps a moment of doubt in the period when his political views were changing. I remember a conversation with him, some time in the early $1970 \mathrm{~s}$. He made a remark that caused me to exclaim: "What? You regret that you took part in making the bomb?". He answered: "You know, there are certain questions about which it is better not to think too much". But this doubt was temporary. Later his struggle for disarmament was intensified because of the danger of the accumulation of stocks of nuclear weapons and of their proliferation. I heard at second hand that during his meeting with Edward Teller about one year ago he said to him something of the kind: "Essentially, you and I were solving a common problem". On another occasion I myself heard him say, "Teller is a tragic figure".

Sakharov's belief was that one should struggle for non-proliferation, and for reduction of nuclear arsenals as well as of conventional armaments. But he saw this as being possible only in the open world with human rights truly secured. In sum, I am sure that his political and social activities would have followed the same course even if he had not been involved in the making of the bomb.

\section{Human rights}

The great significance of Sakharov's struggle for human rights lies not so much in the practical results of dissidence as in its tremendous moral and spiritual effect. For the first time in many decades people of my country saw a man of extreme honesty, sincerity and nobility who fearlessly faced the state machine - both in proclaiming large-scale political ideas and in defending individuals. He was devoted to his fellow fighters for human rights. $\mathrm{He}$ was ready to struggle for every one of them, and never missed a chance to call attention to those who were in jail or exile. The names of such people were included in his Nobel lecture and in his letters to the government. When Gorbachev told him that he was free he immediately responded that all of them also should be liberated. When later he was told that his honours (of which he had been deprived when sent to exile) were to be returned to him, he refused to take them back until all dissidents were rehabilitated.

This indivisible combination of deep feelings for humanity as a whole and for single individuals was the most remarkable feature of Sakharov's personality. Together with his absolute inability to say anything that did not correspond with his convictions, with what he actually thought and felt, it explains why both ordinary people and the political leaders of the world listened to and trusted him. At the same time he did not claim to be a deity. Once, in the middle of the 1970 s, I said to him: "You know, Andrei Dmitrievich, some of your admirers nevertheless believe that neither yourself or Solzhenitzyn should give recommendations concerning concrete political and economic problems since you are not professionals". $\mathrm{He}$ exclaimed: "Of course, I am not a professional, of course, I make errors. But what am I to do if nobody else can or dares to say a word?"

A year or so ago, I asked him whether certain recollections about his younger years were true. He became indignant: "All this is a myth to make a superman of me. I am a man like others". It would be unjust to suspect that here he was posturing; he simply meant that although he knew his worth, he did not want to feel himself to be apart from other people. And he was not. We have lost one of the finest examples of humanity.

E. L. Feinberg is in the P.N. Lebedev Physical Institute, USSR Academy of Sciences, Leninsky Prosp. 53, 117924 Moscow, USSR. 